\title{
BAGAIMANA AGAR PENYANDANG TUNA DAKSA MAMPU MENJADI PRIBADI YANG BAHAGIA?
}

Femita Adelina

Fakultas Psikologi, Universitas Airlangga

femita.adel@gmail.com

Satria Kamal Akhmad

Fakultas Psikologi, Universitas Airlangga

satria.kamal.akhmad-2017@psikologi.unair.ac.id

\section{Cholichul Hadi}

Fakultas Psikologi, Universitas Airlangga

cholichul.hadi@psikologi.unair.ac.id

\begin{abstract}
Abstrak
Menjadi tuna daksa pada saat dewasa atau karena kecelakaan dapat memberikan dampak negatif secara psikologis bagi para penyandangnya. Penelitian ini bertujuan untuk menyajikan perspektif baru terkait proses mendapatkan kebahagiaan dan mengungkap jalan menuju kesejahteraan penyandang tuna daksa karena kecelakaan. Penelitian ini menggunakan pendekatan kualitatif dengan metode studi kasus instrumental. Partisipan dalam penelitian ini adalah dua laki-laki penyandang tuna daksa karena kecelakaan. Teknik pengumpulan data menggunakan teknik wawancara mendalam. Data yang terkumpul dianalisis dengan menggunakan teknik analisis tematik. Hasil penelitian menunjukkan bahwa dukungan sosial merupakan faktor penting yang menentukan kesejahteraan penyandang tuna daksa pasca kecelakaan. Dukungan keluarga dan jejaring sosial (teman dan anggota komunitas tuna daksa) mampu membangkitkan semangat hidup tuna daksa pasca mengalami kecelakaan serta mampu membuat hidup mereka menjadi lebih bahagia.
\end{abstract}

Kata Kunci: cacat tubuh, dukungan sosial, kesejahteraan

\begin{abstract}
Being physically disabled at adulthood or because of an accident can have a psychological negative impact on the person affected. This study aims to present new perspectives related to the process of gaining happiness and uncovering the road to the welfare of disabled people due to accidents. This study uses a qualitative approach with instrumental case study methods. Participants in this study were two men with disabilities due to an accident. Data collection techniques using in-depth interview techniques. The collected data was analyzed using thematic analysis techniques. The results of the study indicate that social support is an important factor that determines the welfare of post-accident disabled people. Family support and social networking (friends and members of the disabled community) were able to raise the spirit of life for the physically disabled after an accident and be able to make their lives happier.
\end{abstract}

Keywords: disability, social support, welfare

Jumlah penyandang disabilitas di dunia cukup besar, setidaknya $10 \%$ populasi di dunia menderita disabilitas fisik, mental, dan sosial. Sementara $80 \%$ dari penderita disabilitas tersebut berada di negara-negara berkembang (Forouzan, 2013). Data PUSDATIN dari kementerian sosial tercatat bahwa pada tahun 2010 jumlah penyandang disabilitas mencapai 11.580 .117 orang dan 3.010.830 orang diantaranya merupakan penyandang disabilitas fisik (tuna daksa). Kementerian Ketenagakerjaan dan Transmigrasi RI mencatat jumlah penyandang disabilitas tahun 2010 sebanyak 7.126.409 orang dan sebanyak 1.852 .866 orang merupakan penyandang tuna daksa (Poerwanti, 2017). Sementara itu jumlah penyandang disabilitas di Indonesia pada tahun
2012 menurut Data PPLS (Program Perlindungan dan Layanan Sosial) sebesar 2,45\% dari jumlah penduduk dan 263.879 diantaranya merupakan penyandang disabilitas fisik (Diono, 2014). Besarnya jumlah penyandang disabilitas di Indonesia tidak sebanding dengan perhatian dari pemerintah untuk menangani permasalahan yang dihadapi oleh penyandang disabilitas secara umum, termasuk pada disabilitas fisik (tuna daksa).

Menjadi tuna daksa pada saat dewasa atau tidak sejak lahir terlebih lagi karena kecelakaan dapat memberikan dampak negatif secara psikologis bagi para penyandangnya. Seringkali penyandang tuna daksa merasa inferior. Bahkan kondisi ini juga menimbulkan 
ketidakbahagiaan serta menghambat jalan bagi tuna daksa untuk menuju kesejahteraan.

Dari latar belakang diatas maka peneliti tertarik untuk mengetahui bagaimana penyandang tuna daksa mampu menjadi pribadi yang bahagia. Penelitian ini bertujuan untuk menyajikan perspektif baru terkait proses mendapatkan kebahagiaan dan mengungkap jalan menuju kesejahteraan penyandang tuna daksa karena kecelakaan.

Definisi tuna daksa secara spesifik yaitu suatu bentuk kelainan atau kecacatan pada sistem otot, tulang, persendian dan syaraf yang disebabkan oleh penyakit, virus, dan kecelakaan baik yang terjadi sebelum lahir, saat lahir, maupun setelah kelahiran (Somatri, 2006; Megasari, 2016). Adapun tingkat gangguan pada tuna daksa dapat dikelompokkan menjadi tiga jenis yaitu ringan, sedang, dan berat. Gangguan atau kerusakan tersebut dapat terjadi pada masa sebelum lahir (fase prenatal), saat kelahiran (fase natal), dan setelah proses kelahiran (fase postnatal) (Somatri, 2006; Megasari, 2016).

Keterbatasan yang dimiliki penyandang tuna daksa dapat mempengaruhi kondisi psikologisnya. Keterbatasan membuat tuna daksa didiskrimasi dan akhirnya merasa tertekan. Menurut Lusli (dalam Merdiasi, 2013) terdapat dua jenis perlakuan negatif yang diterima oleh penyandang tuna daksa, yaitu pemberian label berdasarkan penampilan fisik dan tidak adanya aksesibilitas (kemudahan bagi tuna daksa guna mewujudkan kesamaan kesempatan dalam segala aspek kehidupan).

Senra (dalam Puspasari dan Alfian, 2012; Arianti dan Partini, 2017) menyebutkan beberapa dampak psikologis yang dialami penyandang tuna daksa diantaranya depresi, trauma, marah, shock, tidak dapat menerima keadaan/stress, dan berpikir untuk bunuh diri. Setyowati dkk. (dalam Arianti dan Partini, 2017) dalam studinya tentang penyandang tuna daksa karena kecelakaan menunjukkan bahwa $56 \%$ responden memiliki tingkat depresi sedang dan tinggi, sedangkan $44 \%$ sisanya mengalami depresi pada tingkat ringan hingga normal. Penelitian lain yang dilakukan oleh Sulaeman (dalam Tentama, 2014) menunjukkan bahwa kondisi fisik yang menjadi tidak sempurna karena kecelakaan dapat membuat individu tidak dapat menerima kondisi dirinya sendiri sehingga ia akan mencerca diri sendiri, memandang orang lain secara tidak adil, menolak dirinya, suka menyakiti diri sendiri dan sering berbuat sesuatu yang menyebabkan orang lain memandang rendah kepada dirinya.

Dampak psikologis dari pengalaman-pengalaman negatif di lingkungan sosialnya dapat menyebabkan penyandang tuna daksa tidak dapat merasakan kebahagiaan dalam menjalani hidupnya pasca kecelakaan.
Kebahagiaan merupakan hal yang bersifat subjektif. Seorang individu dengan individu lainnya bisa jadi mengartikan kebahagiaan dengan cara yang berbeda. Kebahagiaan yang dirasakan oleh penyandang tuna daksa bisa jadi berbeda dengan kebahagiaan yang dirasakan oleh individu dengan kondisi normal. Banyaknya perilaku dan pengalaman negatif yang disebutkan di atas bisa jadi menghambat atau mengurangi kebahagiaan penyandang tuna daksa.

Terdapat dua unsur yang harus dipenuhi agar tuna daksa dapat mendapatkan kebahagiaan (Khairina, 2013). Unsur yang pertama adalah afeksi. Perasaan dan emosi merupakan bagian yang tidak dapat dipisahkan. Setiap pengalaman emosional selalu berhubungan dengan afektif atau perasaan yang menyenangkan hingga tidak menyenangkan. Unsur yang kedua adalah kepuasan hidup. Kepuasan hidup merupakan kualitas dari kehidupan seseorang yang telah teruji secara keseluruhan berdasarkan kriteria yang telah ditentukan. Kepuasaan hidup merupakan hasil dari perbandingan antara peristiwa yang dialami dengan harapan atau keinginan. Dengan kata lain, semakin terpenuhinya harapan, maka semakin tinggi pula kepuasan hidup seorang individu. Berdasarkan latar belakang tersebut peneliti merasa tertarik untuk menganalisis faktor yang dapat membuat penyandang tuna daksa agar menjadi pribadi yang bahagia.

\section{METODE}

Penelitian ini merupakan penelitian kualitatif dengan menggunakan studi kasus instrumental yang dipilih untuk mencermati secara mendalam, mengkaji secara menyeluruh, dan mengungkap motif-motif baik internal maupun eksternal terkait konteks kebahagiaan pada penyandang tuna daksa. Pemilihan informan dilakukan berdasarkan kriteria yaitu individu yang mengalami cacat tubuh atau menjadi tuna daksa karena kecelakaan. Jumlah partisipan dalam penelitian ini dua orang laki-laki yang merupakan tuna daksa karena kecelakaan. Kedua partisipan merupakan anggota dari komunitas tuna daksa di Kabupaten Tulungagung. Adapun kriteria significant other yang dipilih dalam penelitian ini adalah individu yang mengenal baik partisipan yaitu keluarga dan teman partisipan. Teknik pengumpulan data menggunakan teknik wawancara mendalam. Data yang terkumpul dianalisis dengan menggunakan teknik analisis tematik.

\section{HASIL DAN PEMBAHASAN}

\section{Kehidupan Penyandang Tuna Daksa}

Tuna daksa merupakan gangguan atau kerusakan pada otot, tulang dan persendirian yang dapat mengakibatkan gangguan koordinasi, komunikasi, adaptasi, dan mobilisasi. Hal tersebut dialami oleh kedua partisipan 
dalam penelitian ini. Penyandang tuna daksa karena kecelakaan mengatakan bahwa mereka berbeda dengan individu pada umumnya karena keterbatasan yang mereka miliki. Sebelum mengalami kecelakaan mereka dapat bekerja layaknya orang pada umumnya, namun pasca mengalami kecelakaan mereka tidak dapat bekerja seperti sebelumnya. Kecelakaan yang mereka alami membuat salah satu anggota tubuh mereka (kaki) tidak dapat berfungsi dan harus diamputasi.

Perubahan kondisi fisik dari sempurna atau lengkap menjadi tidak sempurna atau mengalami gangguan membuat penyandang tuna daksa merasa inferior. Perasaan semacam ini muncul pada saat awal amputasi kaki. Merasa takut ditolak lingkungan sosial dan menjadi bahan perbincangan merupakan alasan mereka takut untuk bergaul lagi dengan orang-orang di lingkungannya. Selain itu perasaan sedih dan putus asa juga dialami oleh penyandang tuna daksa pasca amputasi. Kondisi yang dialami membuat penyandang tuna daksa berfikir bahwa mereka sudah tidak dapat melakukan apa-apa. Untuk melakukan beberapa aktivitas mereka juga harus dibantu oleh anggota keluarga lainnya.

Pasca kecelakaan, penyadang tuna daksa merasa terbantu dengan bantuan dari keluarga. Meskipun pada awalnya keluarga terkejut atas kondisi yang dialami tuna daksa tersebut, namun mereka tetap berusaha untuk memberikan semangat untuk tetap tegar menghadapi kondisi tersebut. Kondisi penyandang tuna daksa yang cukup tertekan dapat sedikit terkurangi karena dorongan keluarga. Keluarga secara terus menerus memberikan motivasi dan dorongan kepada penyandang tuna daksa untuk bangkit lagi dari kondisi tersebut.

Keluarga penyandang tuna daksa tidak hanya memberikan bantuan secara moril, namun juga secara materil, salah satunya dengan mencari pekerjaan untuk memenuhi kebutuhan. Hal ini dilakukan oleh istri penyandang tuna daksa pasca suami mereka tidak mampu bekerja seperti sedia kala. Bahkan beberapa saudara memberikan pinjaman uang untuk biaya pengobatan. Keterbatasan mobilitas pada akhirnya memaksa para tuna daksa untuk memilih mendirikan usaha kecil-kecilan di rumah.

Perasaan inferior dan putus asa yang dialami oleh penyandang tuna daksa berangsur hilang ketika mereka bergabung dengan sebuah komunitas khusus yang hanya beranggotakan penyandang tuna daksa. Di dalam komunitas tersebut penyadang tuna daksa merasa bahwa mereka tidak sendiri di dunia ini. Bergabung dengan komunitas tersebut membuat para tuna daksa merasa senasib dengan anggota lainnya. Pasca bergabung dengan komunitas tersebut, penyandang tuna daksa bahkan berpikir bahwa kondisi mereka bisa dikatakan lebih beruntung daripada beberapa anggota lainnya. Mereka masih beruntung karena pernah memiliki anggota tubuh yang lengkap dan berfungsi sempurna, sementara beberapa anggota komunitas tuna daksa lainnya merupakan penyandang tuna daksa bawaan (sejak lahir), dengan kata lain mereka tidak pernah merasakan atau mempunyai anggota tubuh yang lengkap dan berfungsi secara sempurna.

Menjadi bagian dari komunitas tuna daksa membuat para penyandang tuna daksa lebih percaya diri dengan kondisi mereka pasca kecelakaan. Mereka juga mengatakan bahwa anggota di komunitas tersebut saling memberikan semangat kepada anggota lainnya. Anggota komunitas saling menghibur anggota lainnya untuk mengurangi perasaan negatif atas kondisi yang dialami. Ketua komunitas tersebut bahkan mengatakan bahwa perubahan sebelum dan setelah bergabung dengan komunitas cukup terlihat pada para anggota komunitas tersebut, termasuk pada kedua partisipan.

Adanya dukungan dari teman-teman komunitas membuat penyandang tuna daksa mampu melanjutkan hidup seperti sebelumnya. Bergabung dengan komunitas tuna daksa membuat penyandang tuna daksa merasa bahagia karena memiliki teman untuk berbagi cerita tentang masalah atau kondisi yang dihadapi. Perasaan diterima dan dicintai mereka rasakan ketika menjadi bagian dari komunitas ini.

\section{Penyandang Tuna Daksa Menggapai Bahagia dan Sejahtera}

Kebahagiaan seorang individu dapat tercapai apabila individu tersebut secara afeksi merasa bahagia dan secara kognisi merasa puas dengan kehidupannya. Namun suatu kondisi yang dialami penyandang tuna daksa karena kecelakaan bisa jadi menghambat tercapainya kebahagiaan tersebut. Hal itu dikarenakan oleh perubahan kondisi fisik, mengalami kesulitan dalam beraktivitas seperti semula, serta merasa inferior dan putus asa. Perubahan fisik dari normal menjadi kehilangan salah satu anggota tubuh menyebabkan penyandang tuna daksa merasa inferior. Inferioritas penyandang tuna daksa membuat mereka takut untuk bergaul dengan orangorang di sekitar mereka sehingga mereka cenderung membatasi interaksi mereka dengan dunia luar dan kemudian juga berpengaruh kepada kebahagiannya.

Salah satu konsep psikologis yang menggambarkan kebahagiaan individu adalah subjective well being. Menurut Diener (dalam Al-Karimah, 2018), subjective well being adalah pengalaman setiap individu yang merupakan penilaian positif atau negatif secara khas mencakup penilaian dari seluruh aspek kehidupan individu. Menurut konsep ini, seorang individu memiliki kesejahteraan psikologis apabila individu tersebut merasa bahagia secara afeksi dan puas dengan 
kehidupannya secara kognisi. Dengan demikian subjective well being dapat diartikan sebagai keseluruhan evaluasi seorang individu terhadap afeksi dan kognisi atas kualitas hidupnya.

Penyandang tuna daksa rentan memiliki kebahagiaan yang rendah baik karena faktor intern maupun faktor ekstern. Faktor intern merupakan faktor yang ada dalam diri penyandang tuna daksa, seperti tidak mampu menerima kondisinya. Sedangkan faktor ekstern merupakan faktor yang berasal dari lingkungan sosial penyandang tuna daksa, seperti penolakan dan ejekan dari orang-orang di sekitarnya. Mencerca, menertawakan, menolak kehadiran, dan bahkan diskriminasi di tempat kerja merupakan beberapa contoh perilaku negatif yang dilakukan oleh masyarakat kepada penyandang tuna daksa.

Kebahagiaan individu berkaitan dengan hubungan individu dengan lingkungan sosialnya. Pavot dan Diener (dalam Linely dan Joseph, 20014; Alkarimah, 2018) mengatakan bahwa salah satu faktor yang mempengaruhi kesejahteraan individu adalah hubungan sosial. Adanya hubungan positif seorang individu dengan individuindividu lain di sekitarnya membuat individu tersebut merasa bahagia karena ia merasa mendapatkan dukungan sosial. Adanya dukungan dari individu lain juga menyebabkan munculnya kedekatan emosional pada individu tersebut. Hal ini didukung oleh penelitian Tough dkk. (2017) yang menyatakan bahwa hubungan sosial memainkan sebuah peran penting dalam kesehatan mental dan kesejahteraan individu yang mengalami disabilitas. McLaughlin dkk (dalam Wang, 2014) menggambarkan bahwa ukuran dari jejaring sosial memiliki dampak positif terhadap subjective well being. Penelitian lain yang dilakukan oleh Symister (dalam Wang, 2014) menunjukkan bahwa adanya persepsi yang bagus atas dukungan jejaring sosial dianggap membantu mengurangi tekanan hidup dan meningkatkan kesehatan tubuh dan pikiran. Compton (dalam Mujamiasih, 2013) mengatakan bahwa subjective well being terdiri dari dua variabel utama yaitu kebahagiaan dan kepuasaan hidup. Kebahagiaan berkaitan dengan keadaan emosional individu dan bagaimana individu merasakan diri dan dunianya, sedangkan kepuasan hidup merupakan penilaian secara menyeluruh tentang kemampuan individu menerima hidupnya.

\section{Dukungan Sosial Sebagai Modal untuk Berproses menjadi Bahagia dan Sejahtera}

Dari hasil anilsis tematik, muncullah dukungan sosial sebagai bentuk sekaligus faktor yang paling berkontribusi terhadap penyandang tuna daksa untuk mendapatkan kebahagiaan serta melapangkan jalan menunju kesejahteraan. Kesejahteraan (well being) yang dimiliki oleh penyandang tuna daksa sangat erat kaitannya dengan dukungan sosial yang diperolehnya. Dukungan sosial pada penyandang tuna daksa berasal dari jejaring sosialnya seperti keluarga dan teman-temannya.

Dukungan sosial penting untuk mengurangi dampak negatif yang muncul dari stres yang dapat mempengaruhi subjective well being seorang individu (Larasati, 2017). Bishop (dalam Poegoeh, 2016) mendeskripsikan dukungan sosial sebagai pertolongan dan dukungan yang diperoleh seseorang dari interaksinya dengan orang lain dimana bantuan tersebut akan menaikkan perasaan positif serta mengangkat harga diri sehingga akan berdampak pada kesejahteraan individu secara umum. Sarafino (2002) mendeskripsikan dukungan sosial sebagai kenyamanan, perhatian, penghargaan, maupun bantuan dalam bentuk lainnya yang diterima individu dari individu lain maupun dari kelompok.

Penyandang tuna daksa mengaku dapat menerima dan puas akan kehidupannya saat ini. Perubahan kondisi fisik yang dialami pada saat dewasa atau perubahan fisik yang terjadi karena kecelakaan tidak membuat penyandang tuna daksa terus menerus bersikap dan berpikiran negatif atas dirinya. Penyandang tuna daksa mampu memandang hidupnya secara positif dan bangkit dari kondisi yang dialami. Kepuasan akan kehidupan saat ini dan adanya optimisme serta kebahagiaan dalam menghadapi kehidupan merupakan bentuk tercapainya subjective well being pada penyandang tuna daksa. Meskipun pada awalnya penyandang tuna daksa memandang hidupnya secara negatif, namun adanya kontak sosial yang positif dengan lingkungan sosialnya membuat penyandang tuna daksa mampu menerima kondisinya serta memandang dirinya lebih positif.

Beberapa peneliti membagi atau mengelompokkan dukungan sosial ke dalam beberapa bentuk. Sarafino (2002) mengelompokkan dukungan sosial ke dalam lima bentuk, diantaranya dukungan emosional, dukungan penghargaan, dukungan informasi, dukungan instrumental, dan dukungan kelompok (jaringan sosial). Sedangkan Fiona dan Fajrianti (2013) membagi dukungan sosial ke dalam tiga bentuk, yaitu dukungan emosional, dukungan instrumental, dan dukungan informasi. Sedangkan Cohen dan Hoberman (dalam Isnawati dan Suhariadi, 2013) membagi dukungan sosial menjadi empat bentuk, yaitu appraisal support, tangiable support, self esteem support, dan belonging support.

Myers (dalam Gunawan dkk., 2016) mengatakan bahwa dukungan sosial dapat diperoleh dari orang-orang yang memiliki hubungan dekat dengan individu seperti sanak keluarga, teman, atau anggota organisasi. Hal yang serupa disampaikan oleh Goldberger dan Bresnitz (dalam Maziyah, 2015), bahwa dukungan sosial dapat berasal 
dari orang tua, saudara kandung, anak-anak, kerabat, pasangan hidup, sahabat rekan sekerja, dan tetangga. Namun dukungan fundamental yang diperlukan oleh penyandang tuna daksa adalah dukungan dari keluarga. Dukungan dari anggota keluarga kepada penyadang tuna daksa terdiri atas dukungan moril dan materil. Keluarga disini sebagai social support system yang berarti keluarga sebagai sarana terdekat bagi individu yang membutuhkan dukungan sosial. Keluarga merupakan tempat pertama penyandang tuna daksa kembali pasca menjalani amputasi kaki. Selain harus dapat menerima kondisi dirinya sendiri pasca kecelakaan, keluarga penyandang tuna daksa terlebih dahulu harus dapat menerima kondisi salah satu anggota keluarganya tersebut. Keluarga yang mampu menerima kondisi anggota keluarganya yang mengalami disabilitas akan mampu memberikan dukungan secara penuh sehingga penyandang tuna daksa mampu bangkit. Chow (dalam Poegoeh, 2016) mengatakan bahwa dukungan sosial dalam keluarga dapat menurunkan tingkat kerentanan stres dan meningkatkan kemampuan individu dalam menghadapi dan mengatasi masalah yang menimbulkan stres.

Selain itu keterbatasan yang dimiliki penyandang tuna daksa membuat mereka tidak dapat melakukan banyak hal sendiri sehingga beberapa aktivitas perlu bantuan dari orang lain. Bahkan pekerjaan yang ditekuni semula harus digantikan dengan pekerjaan yang sesuai dengan kondisi mereka saat ini. Dari sini dukungan materil sangat diperlukan oleh penyandang tuna daksa. Bentuk dukungan materil dari keluarga adalah keikutsertaan anggota keluarga lainnya untuk membantu memenuhi kebutuhan sehari-hari.

Selain dukungan keluarga, dukungan dari jejaring sosial lainnya juga dibutuhkan oleh penyandang tuna daksa. Dukungan sosial yang cukup besar diperoleh penyandang tuna daksa saat bergabung dengan komunitas khusus bagi tuna daksa. Di dalam komunitas tersebut para anggota saling memberi nasihat, saran, petunjuk, serta umpan balik melalui kegiatan sharing yang ada dalam kelompok. Dengan kata lain, penyandang tuna daksa memperoleh dukungan informasi dari para anggota kelompok di komunitas tersebut. Adanya dukungan informasi berupa nasihat dan saran dari para anggota komunitas yang mengalami keadaan yang sama mampu membantu penyandang tuna daksa untuk memahami situasi dan mencari alternatif pemecahan masalah atau tindakan yang akan diambil.

Menjadi bagian dari komunitas tuna daksa membuat penyandang tuna daksa merasa nyaman. Perasaan takut untuk bergaul atau bersosialisasi dengan lingkungan sekitar perlahan berkurang dan bahkan menghilang. Perasaan empati, kepedulian, dan perhatian yang diperoleh oleh penyandang tuna daksa dari kelompoknya merupakan bentuk dari dukungan emosional. Adanya dukungan emosional dapat memberikan rasa nyaman, kepastian, perasaan memiliki, dan dicintai dalam diri mereka.

Di dalam komunitas tersebut penyandang tuna daksa diterima dengan baik dan dihormati oleh anggota lainnya. Hal ini merupakan bentuk dari dukungan penghargaan. Dukungan penghargaan yang diterima oleh para penyandang tuna daksa berupa ungkapan-ungkapan positif, pemberian dorongan untuk maju atau bangkit, serta persetujuan atas ide atau gagasan-gagasan yang diberikan oleh penyandang tuna daksa. Dukungan penghargaan ini membuat penyandang tuna daksa membangun perasaan berharga, kompeten, dan bernilai.

Penyandang tuna daksa juga mendapatkan bantuan berupa barang dari komunitas tersebut. Selain mendapatkan bantuan barang, penyandang tuna daksa juga memperoleh bantuan berupa pelatihan keterampilan. Bantuan barang dan pelatihan keterampilan kepada penyandang tuna daksa merupakan bentuk dari dukungan instrumental. Dukungan instrumental merupakan bentuk dukungan secara langsung yang diperoleh penyandang tuna daksa dari kelompoknya.

Di dalam komunitas, penyandang tuna daksa memiliki perasaan bahwa mereka merupakan anggota kelompok yang memiliki minat yang sama serta memiliki rasa kebersamaan dengan anggota lain di kelompok tersebut. Hal ini merupakan bentuk dari adanya dukungan kelompok (jejaring sosial). Dukungan semacam ini mampu membantu individu dalam mengurangi stres yang dialami dengan cara memenuhi kebutuhan akan kontak sosial. Kontak sosial yang dilakukan dengan individu lain yang mempunyai minat yang sama membantu penyandang tuna daksa untuk untuk membangun pikiran serta suasana hati yang positif.

Dukungan-dukungan sosial yang diperoleh penyandang tuna daksa dari berbagai sumber baik keluarga maupun jejaring sosial lainnya nya dapat mengurangi rasa takut dan kecemasan karena perubahan kondisi fisik yang dialami. Sebagaimana yang disampaikan oleh Maziyah (2015) bahwa individu yang mendapat dukungan sosial tinggi akan mengalami hal-hal positif dalam hidupnya, mempunyai self esteem yang lebih tinggi, self concept yang lebih baik, dan kecemasan yang lebih rendah. Reaksi lingkungan akan memberikan pengaruh terhadap tuna daksa karena pengalaman yang dialami penyandang tuna daksa secara langsung akan lebih mudah diingat. Jika yang diterima penyandang tuna daksa merupakan perilaku atau reaksi-reaksi yang bersifat negatif, maka penyandang tuna daksa akan langsung menyalahkan dirinya atas kondisi tubuhnya yang kemudian berpengaruh terhadap rendahnya self esteem dan buruknya self concept. Sebaliknya jika 
penyandang tuna daksa memperoleh perilaku atau reaksireaksi yang positif dari lingkungannya, maka penyandang tuna daksa akan memiliki self esteem yang lebih tinggi dan self concept yang baik. Sehingga jelas disini bahwa dukungan sosial yang diterima oleh tuna daksa mampu menjadikan tuna daksa menjadi pribadi yang lebih bahagia.

\section{SIMPULAN}

Penyandang tuna daksa mampu menjadi pribadi yang bahagia ketika secara afektif mereka merasa bahagia dan optimis akan kehidupannya dan secara kognitif mereka merasa puas dengan kehidupannya. Di dalam psikologi konsep yang tepat untuk menggambarkan kebahagiaan adalah subjective well being. Subjective well being dapat tercapai dengan adanya kontak sosial antara penyandang tuna daksa dengan orang-orang di sekitarnya. Kontak sosial yang positif membuat penyandang tuna daksa merasakan adanya dukungan dari orang-orang di sekitarnya. Kontak sosial inilah yang mampu meningkatkan kondisi psikologis penyandang tuna daksa menjadi lebih positif daripada sebelumnya. Dengan demikian dapat disimpulkan bahwa dukungan sosial merupakan faktor yang berkontribusi utama serta yang dibutuhkan penyandang tuna daksa khususnya penyandang tuna daksa karena kecelakaan untuk menjadi pribadi yang lebih bahagia.

\section{DAFTAR PUSTAKA}

Al-Karimah, N. F. 2018. Subjective Well-Being Pada Penyandang Tuna Daksa. Jurnal Psikosains Vol. 13 No. 1, Februari 2018, 57-64.

Arianti, E. F. dan Partini. 2017. Tingkat Depresi Ditinjau dari Latar Belakang Penyebab Kecacatan Pada Penyandang Tuna Daksa. Indigenous: Jurnal Ilmiah Psikologi, Vol. 2 No. 2.

Diono, A. 2014. Program Rehabilitasi Sosial Penyandang Disabilitas dan Pergeseran Paradigma Penanganan Penyandang Disabilitas. Buletin Jendela Data dan Informasi: Situasi Penyandang Disabilitas, Semester II, 2014. Kementerian Kesehatan RI

Fiona, K. dan Fajrianthi. 2013. Pengaruh Dukungan Sosial terhadap Kualitas Hidup Penderita Skizofrenia. Vol. 02 No. 03 Jurnal Psikologi Kepribadian dan Sosial. Fakultas Psikologi Universitas Airlangga.

Forouzan, A. S. 2013. Perceived Social Support Among People with Physical Disability. Iranian Red Crescent Medical Journal, Vol. 15 No. 8, 663-7.

Gunawan, A. R dkk. 2016. Dukungan Sosial Orang Tua Terhadap Atlet Paralimpik Pelajar Tuna Netra
Berprestasi di Kota Bandung. Prosiding KS: Riset dan PKM Vol. 3 No. 3, 292-428.

Isnawati, D. dan Suhariadi, R. 2013. Hubungan antara Dukungan Sosial dengan Penyesuaian Diri Masa Persiapan Pensiun Pada Karyawan PT Pupuk Kaltim. Jurnal Psikologi Industri dan Organisasi Vol. 1, Februari 2013, 1-6.

Khairina, N. N. 2013. Makna Bahagia Bagi Penyandang Cacat Fisik (Tuna Daksa). Skripsi. Fakultas Psikologi Universitas Islam Negeri Malang.

Larasati, I. 2017. Hubungan antara Dukungan Sosial dan Optimisme dengan Subjective Well Being Pada Remaja Tuna Daksa di BBRSBD Prof. Dr. Soeharso Surakarta. Skripsi. Program Studi Psikologi Fakultas Kedokteran Universitas Sebelas Maret Surakarta.

Maziyah, F. 2015. Hubungan Dukungan Sosial dengan Tingkat Kecemasan dalam Mengerjakan Skripsi Pada Mahasiswa Sekolah Tinggi Ilmu Kesehatan (STIKES) NU Tuban. Skripsi. Fakultas Psikologi Universitas Islam Maulana Malik Ibrahim Malang.

Megasari, A. P. 2016. Hubungan Penerimaan Diri dan Kebermaknaan Hidup Pada Remaja Tuna Daksa. Tugas Akhir Program Studi Psikologi, Fakultas Psikologi Universitas Kristen Satya Wacana Salatiga.

Merdiasi, D. 2013. Gambaran Tuna Daksa Yang Bekerja. Jurnal NOETIC Psychology Vol. 3 No. 2, JuliDesember.

Mujamiasih, M. 2013. Subjective Well Being (SWB): Studi Indigenous Pada PNS dan Karyawan Swasta yang Bersuku Jawa di Pulau Jawa. Skripsi. Program Studi Psikologi Fakultas Ilmu Pendidikan Universias Negeri Semarang.

Poegoeh, D. P. 2016. Peran Dukungan Sosial dan Regulasi Emosi terhadap Resiliensi Keluarga Penderita Skizofrenia. INSAN Vol. 1 No. 1, Juni 2016.

Poerwanti, S. D. 2017. Pengelolaan Tenaga Kerja Difabel Untuk Mewujudkan Workplace Inclusion. INKLUSI: Journal of Disability Studies Vol. 4 No. $1,1-24$.

Sarafino, E. P. 2002. Health Psychology: Biopsychosocial Interactions. $2^{\text {nd }}$ ed. New John Wiley and Sons Inc.

Tentama, F. 2014. Hubungan Positive Thinking dengan Self Acceptance Pada Difabel (Bawaan Lahir) di SLB Negeri 3 Yogyakarta. Jurnal Psikologi Positif Integratif Vol. 2 No. 2, 1-7.

Tough, H. dkk. 2017. Social Relationship, Mental Health and Well Being in Physical Disability: A Systematic Review. BMC Public Health Vol. 17, 414.

Wang, X. 2014. Subjective Well Being Associated With Size of Social Network and Social Support of 
125 | Jurnal Sains Psikologi, Jilid 7, Nomor 2, November 2018, hlm 119-125

Elderly. Journal of Health Psychology Vol. 21 Issue. 6, 1037-1042 